\title{
STUDI PERBANDINGAN PEMAKAIAN PRIMER HBS1 DAN HBS2 DENGAN PRIMER P7 DAN P8 DALAM DETEKSI DNA VIRUS HEPATITIS B PADA PENDONOR DARAH
}

\author{
Supiana Dian Nurtjahyani ${ }^{1}$, Mohammad Amin ${ }^{2}$, Retno Handajan ${ }^{3}$ \\ ${ }^{1}$ Department of Biology Education, Faculty of Teaching and Education Science PGRI Ronggolawe \\ University, Tuban, East Java, Indonesia, \\ ${ }^{2}$ Institute of Tropical Disease and ${ }^{3}$ Department of Biochemistry, Faculty of Medicine, Airlangga \\ University, Surabaya, East Java, Indonesia \\ Email: diantbn@yahoo.co.id
}

Diterima: 7 September 2020

Disetujui: 14 September 2020

\begin{abstract}
Examination of the hepatitis B virus as a disease of hepatitis serologically has been carried out a lot, but this serological examination can experience problems if there is a low window period, so even though a negative test result is still possible in a patient's body infected with the hepatitis B virus, a fast and accurate examination is needed. PCR examination is an alternative solution to overcome this problem because the results are more accurate and valid because it can directly detect hepatitis $B$ virus $D N A$ as the cause of hepatitis $B$ infection. This examination requires selecting the right primer so that accurate results are obtained. The aim of this study was to compare the use of HBS1 and HBS2 primers with $P 7$ and P8 primers in the detection of Hepatitis B virus DNA in blood donors. The method used in this study is a laboratory experiment with Polymeration Chain Reaction $(P C R)$ examination. The results showed that the HBS1 and HBS2 primers produced more positive HBV DNA by $76.92 \%$ compared to $P 7$ and P8 primers, only 23.08\%. Conclusion HBS1 and HBS2 primers can detect positive HBV DNA with more results.
\end{abstract}

Kata kunci: DNA Virus hepatitis B, primer HBS1 dan HBS2, primer P7 dan P8

\section{PENDAHULUAN}

Virus hepatitis $\mathrm{B}$ merupakan problema di masyarakat yang masih memerlukan penanganan yang serius. Virus hepatitis B adalah sebuah virus deoxyribonucleic acid (DNA) yang merupakan prototipe dari famili Hepadnaviridae. Virion virus hepatitis $\mathrm{B}$ berdiameter 42 nanometer ( $\mathrm{nm})$, berenvelope, dengan nukleokapsid ekosahedral. Gen VHB terdapat overlap dengan sebagian gen polimerase DNA (Levinson \&Jawetz, 2003), dan merupakan bagian genom DNA sirkuler 3.200 basa, yang mengkode Hepatitis $B$ e Antigen (HBeAg) dan Hepatitis $B$ core Antigen ( $\mathrm{HBcAg}$ ) (Horvat \& Tegtmeier, 2007).

Pemeriksaan virus hepatitis B sebagai penyakit hepatitis secara serologis sudah banyak dilakukan tetapi pemeriksaan serologis ini bisa mengalami kendala bila ada pada masa low windows periode sehingga walaupun hasil pemeriksaan negatif masih di mungkinkan dalam tubuh pasien terinfeksi virus hepatitis B sehingga di perlukan pemeriksaan yang cepat dan akurat. Pemeriksaan PCR merupakan salah satu alternatif solusi untuk mengatasi masalah ini karena hasilnya lebih akurat dan valid karena langsung dapat mendeteksi DNA virus hepatitis B sebagai penyebab infeksi hepatitis B. Pemeriksaan ini memerlukan pemilihan primer yang tepat sehingga di peroleh hasil yang akurat. Tujuan penelitian ini untuk membandingkan pemakaian primer HBS1 dan HBS2 dengan primer P7 dan P8 dalam deteksi DNA Virus Hepatitis B pada pendonor darah.

\section{METODE}

Penelitian ini merupakan penelitian eksperimen laboratorium. Pemeriksaan 
laboratorium dilakukan pada 150 sampel pendonor darah. Tahapan dalam pemeriksaan laboratorium sebagai berikut:

\section{Pemeriksaan DNA VHB dengan Metode PCR}

\section{Ekstraksi DNA VHB}

Ekstraksi DNA VHB dari serum yang sudah diuji HBsAg positip dengan metode ELISA, menggunakan reagen DNAzol (Invitrogen) yang sesuai dengan petunjuk reagen. Dalam proses ekstraksi ini juga digunakan etanol, yellow dan blue tips steril, tabung eppendorf $1,5 \mathrm{ml}$ steril.

\section{Amplifikasi dengan PCR}

Reaksi amplifikasi ini juga menggunakan hasil ekstraksi DNA VHB. Untuk PCR first-round mengamplifikasi 541 base pairs (bp) pada gen S (Lusida et al., 2003) menggunakan Primer : P7 (5'GTG GTG GAC TTC TCT CAA TTT TC3') pada posisi 256-278; 100 picomol $(\mathrm{pmol}) /$ mikroliter $(\mu \mathrm{l})$. dan Primer : P8 (5'CGG TAW ${ }^{[\mathrm{A} / \mathrm{T}]}$ AAA GGG ACT $\mathrm{CAM}^{[\mathrm{A} / \mathrm{C}]} \mathrm{GAT}-3$ ') pada posisi $796-776$; $100 \mathrm{pmol} / \mu \mathrm{l}$.

Apabila hasil PCR tersebut diatas negatip, dilakukan PCR second-round mengamplifikasi 259 bp pada gen $\mathrm{S}$ (Lusida et al., 2003) menggunakan Primer : HBS1 (5'-CAA GGT ATG TTG CCC GTT TG3') pada posisi $455-474 ; 100 \mathrm{pmol} / \mu \mathrm{l}$. dan Primer : HBS2 (5'-AAA GCC CTG CGA ACC ACT GA-3') pada posisi 713-694; $100 \mathrm{pmol} / \mu \mathrm{l}$.

PCR dilakukan dengan menggunakan mesin "GeneAmp PCR System 2400 (Perkin Elmer)" masingmasing PCR terdiri dari 40 siklus yang sebelumnya dilakukan Pre-Denaturasi pada suhu $94^{\circ} \mathrm{C}$ selama 5 menit dan kondisi PCR dengan rincian sebagai berikut : Denaturasi pada suhu $94^{\circ} \mathrm{C}$ selama 60 detik, annealing pada suhu $55^{\circ} \mathrm{C}$ selama 60 detik dan elongasi pada suhu $72^{\circ} \mathrm{C}$ selama 75 detik.

\subsection{Visualisasi Hasil Amplifikasi}

Hasil PCR divisualisasikan dengan proses elektroporesis yang menggunakan bufer TBE 0,5X dan menggunakan gel agarose $2 \%$ yang mengandung ethidium bromide, kemudian dilakukan penyinaran dengan Ultra Violet (UV) transiluminator dan didokumentasi. Marker yang digunakan 100bp marker DNA leadder .

\section{HASIL DAN PEMBAHASAN}

Hasil Pemeriksaan VHB sampel Donor Darah di PMI di KabupatenTuban

\begin{tabular}{|c|c|c|c|c|c|c|}
\hline \multirow{3}{*}{ No. } & \multirow{3}{*}{$\begin{array}{c}\text { Jenis } \\
\text { Kelamin }\end{array}$} & \multicolumn{4}{|c|}{ Primer PCR VHB } & \multirow{3}{*}{$\begin{array}{l}\text { Total PCR } \\
\text { Positif (\%) }\end{array}$} \\
\hline & & \multicolumn{2}{|c|}{ P 7\&8 } & \multicolumn{2}{|c|}{ HBS1\&HBS2 } & \\
\hline & & + & - & + & - & \\
\hline 1 & Pria & $3(23,08 \%)$ & $10(76,92 \%)$ & $10(76,92 \%)$ & 0 & $13(100 \%)$ \\
\hline 2 & Wanita & 0 & 0 & 0 & 0 & $0(0 \%)$ \\
\hline \multicolumn{2}{|c|}{ Total PCR Positif } & $3(23,08 \%)$ & $10(76,92 \%)$ & $10(76,92 \%)$ & 0 & $100 \%$ \\
\hline
\end{tabular}

Berikut akan ditampilkan gambar hasil PCR DNA Hepatitis B (HBV)yang positif, yang menghasilkan nukleotida sepanjang 541bp dengan primer P7 dan P8, serta 259 bp dengan primer HBS1 dan HBS2.

Untuk 13 sampel dengan HBsAg yang positif, PCR VHB positif pada 3 sampel positif dengan pasangan primer $\mathrm{P} 7$ dan P8 (yaitu sampel nomor 16, 38 dan 41) yang menghasilkan nukleotida sepanjang 541 bp, sedangkan 10 sampel (sampel nomor

15.17,39,40,54,91,95,104,115,dan118) baru positif setelah dilakukan nested PCR dengan primer HBS1 dan HBS2 yang menghasilkan nukleotida sepanjang $259 \mathrm{bp}$. Berikut akan, tampilkan gambar hasil PCR 
DNA VHB yang positif, yang menghasilkan nukleotida sepanjang 541 pasangan basa dan yang menghasilkan nukleotida sepanjang 259 pasangan basa.
Gambar hasil PCR DNA Hepatitis B (HBV) dapat dilihat pada gambar 5.1 dan 5.2 di berikut ini:

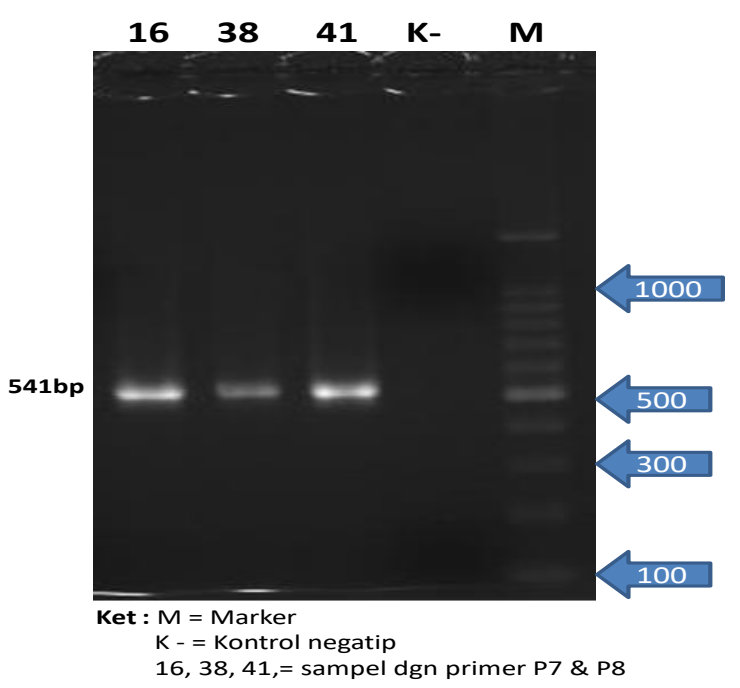

Gambar 1. Hasil PCR DNA Hepatitis B(HBV) panjang 541 bp dengan primer P7 dan P8

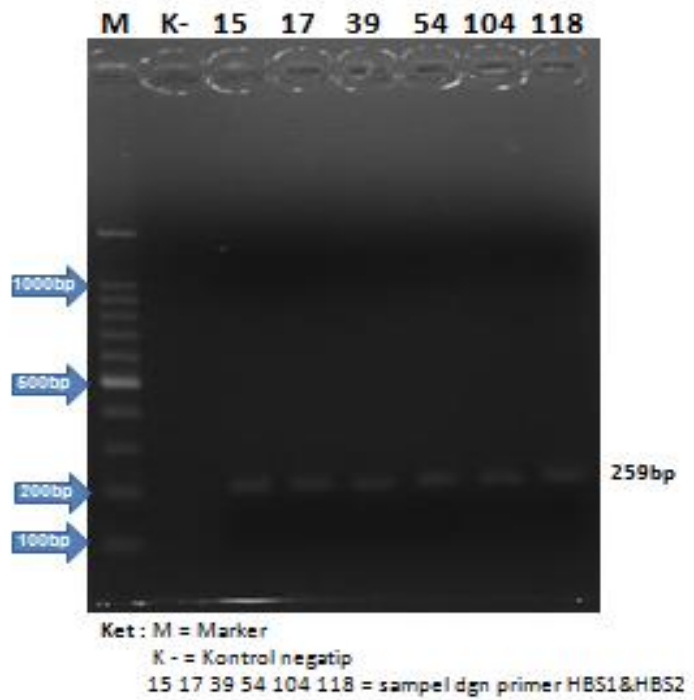

Gambar 2. Hasil PCR DNA Hepatitis B(HBV) panjang 259 bp dengan primer HBS1 dan HBS2

Pemeriksaan PCR dengan primer P7 dan P8 untuk PCR pertama, yang apabila hasil PCR masih negatif, dilanjutkan dengan PCR kedua dengan primer HBS1 dan HBS2. Dari data (tabel 1.) nampak bahwa pada pendonor darah di kabupaten Tuban, laki-laki yang terinfeksi $\mathrm{VHB}=8,67 \%$ dan angka ini lebih tinggi dari wanita yang terinfeksi VHB. Hasil ini sesuai dengan penelitian terdahulu pengidap VHB pada donor darah di sebelas kota besar di Indonesia berkisar 2,1\% sampai 9,5\% , dan di Propinsi Papua sebesar 10,5\%. (Lusida M.I.,et.al.2008). Hasil penelitian ini menunjukkan prosentase DNA VHB pendonor darah di Kabupaten Tuban termasuk cukup tinggi. Perancangan primer yang baik adalah kunci 
keberhasilan dalam proses perbanyakan atau amplifikasi DNA dengan metode ini. Adapun pasangan primer yang optimal yaitu apabila primer tersebut hanya menempel spesifik pada gen targetnya dan apabila proses amplifikasi DNA selesai tidak terbentuk dimer primer (Budiarto, 2015)

Tingginya prosentase DNA VHB pendonor darah di Kabupaten Tuban ini kemungkinan karena Tuban termasuk kota pelabuhan yang walaupun tidak begitu besar tetapi ada mobilitas melalui laut dan mobilitas individu dari desa ke kota tinggi sehingga jalur infeksi terjadi dengan mudah. Hal ini didukung dengan penelitian terdahulu bahwa infeksi VHB di berbagai daerah di Indonesia mempunyai prevalensi infeksi VHB yang berbeda-beda. Di pulau Lombok merupakan daerah hiperendemik, di daerah pedesaan $10,6 \%$ - 20,3\% penduduk merupakan carrier infeksi VHB (Ruff, et al, 1995).

Dari hasil penelitian tersebut terbukti dari 13 sampel $(8,67 \%)$ dengan HbsAg positif setelah dilanjutkan dengan pemeriksaan PCR semuanya penderita dengan DNA VHB positif, dengan primer P7 dan P8 hanya terdeteksi 3 sampel yang DNA VHB positif sedangkan dengan pemakaian primer HBS1 dan HBS2 dapat terdeteksi 10 sampel DNA positif. Hasil ini menunjukkan primer HBS1 dan HBS2 dapat mendeteksi DNA VHB positif dengan hasil yang lebih banyak dibandingkan dengan primer P7 dan P8. Perlu dikemukakan bahwa deteksi materi genetik (contoh DNA VHB) dengan PCR adalah metoda yang sangat peka dan dapat positif lebih dini dari pada pemeriksaan serologis (contoh pemeriksaan HbsAg).

\section{SIMPULAN}

Pemeriksaan PCR pada pendonor dengan primer HBS1 dan HBS2 dapat mendeteksi
DNA VHB postif lebih banyak dibandingkan dengan primer P7 dan P8.

\section{DAFTAR PUSTAKA}

Bugi Ratno Budiarto. (2015). Polymerase Chain Reaction (Perkembangan dan Peranannya dalam Diagnostik Kesehatan). Biotrends.

Horvat, R. T., Tegtmeier, G. E. (2007). Hepatitis B and D Viruses. In Murray, P. R., Baron, E. J., Jorgensen, J. H., Landry, M. L., and Pfaller, M. A. Manual of Clinical Microbiology, American Society for Microbiology, Washington DC: ASM Press, 9(2):1641-1659.

Levinson W, Jawetz E. (2003) Hepatitis viruses. Dalam: Scott D.Holmberg, Anil Suryaprasad, John W.Ward, penyunting. Division of viral hepatitis, National center for HIV/AIDS, viral hepatitis, STD and TB prevention. Medical Microbiology 2 Immunilogy. London: McGraw Hill. 7: 2-9.

Lusida, M. I., Surayah, H. dkk. (2003). Genotype and subtype analyses of hepatitis $B$ virus (HBV) and possible co-infection of HBV and hepatitis $C$ virus (HCV) or hepatitis $\mathrm{D}$ virus (HDV) in blood donors, patients with chronic liver disease and patients on hemodialysis in Surabaya, Indonesia. Microbiol.Immunol. 47: 969-975.

Lusida, M.I., Soetjipto, V.E.N. dkk. (2008). Novel Subgenotypes of Hepatitis B Virus Genotypes C and D in Papua, Indonesia. J. Clin. Microbiol. 46: 2160-2166.

Ruff TA, Gertig DM, Otto BF, dkk. (1995). Lombok Hepatitis B Model Immunization Project: toward universal infant hepatitis B immunization in Indonesia. J.Infect Dis. 171(2): 290-29 